\title{
f dupla função da droga na devastação
}

\author{
La doble función de la droga en la devastación \\ The Double Function of Drug Use on Devastation
}

\author{
Andréia Ferro Siqueira \\ Vinicius Anciães Darriba \\ Universidade do Estado do Rio de Janeiro
}

Doi: https://doi.org/10.12804/revistas.urosario.edu.co/apl/a.7671

\section{Resumo}

Este artigo propõe refletir diferentes funções que o uso de drogas pode ter para um sujeito. Partimos de uma discussão teórica, iniciada com a afirmação do psicanalista Jacques Lacan (1975/1997) de que não haveria "nenhuma outra definição da droga que não seja esta: o que permite romper o casamento com o pequeno-pipi” (p.117). Seguimos com a elaboração de outros psicanalistas, que, ao longo dos anos, descobriram que este consumo pode operar de modo distinto à ruptura do enquadre fálico do gozo. Ele pode, diversamente, limitar os efeitos devastadores do gozo para um sujeito. O artigo busca fundamentar sua argumentação na análise de um caso clínico, que, justamente, leva à discussão da premissa lacaniana, mostrando que o uso de drogas não se deixa reduzir a uma única função.

Palavras chave: psicanálise; gozo; uso de drogas; devastação.

\section{Resumen}

Este artículo propone reflejar diferentes funciones que el uso de drogas puede tener para un sujeto. Partimos de una discusión teórica, iniciada con la afirmación del psicoanalista Jacques Lacan (1975/1997) de que no habría "ninguna otra definición de la droga que no sea esta: lo que permite romper el matrimonio con el petit-pipi" (p.117). Seguimos con la elaboración de otros psicoanalistas, que, a lo largo de los años, descubrieron que este consumo puede operar de modo distinto a la ruptura del encuadre fálico del goce. Él puede, diversamente, limitar los efectos devastadores del goce para un sujeto. El artículo busca fundamentar su argumentación en el análisis de un caso clínico, que, justamente, lleva a la discusión de la premisa lacaniana, mostrando que el uso de drogas no se deja reducir a una única función. Palabras clave: psicoanálisis; goce; uso de drogas; devastación.

Este artigo é produto original de uma dissertação de mestrado intitulada “A devastação e a clínica da toxicomania”, defendida em
2018, no Programa de Pós-Graduação em Psicanálise da Universidade do Estado do Rio de Janeiro, sob a orientação do Professor Dr.
Vinicius Anciães Darriba. Esta pesquisa foi realizada com apoio da Coordenação de Aperfeiçoamento de Pessoal de Nível Superior
- Brasil (capes) - Código de Financiamento 001.
Dirigir correspondência à Andréia Ferro Siqueira. Universidade do Estado do Rio de Janeiro. Correio eletrônico: andreiafs@yahoo.com

Para citar este artigo: Siqueira, A. F., \& Darriba, V. A. (2020). A dupla função da droga na devastação. Avances en Psicología Latinoamericana, 38(3), 1-13. https://doi.org/10.12804/revistas.urosario.edu.co/apl/a.7671 


\section{fibstract}

This article proposes to reflect on the different functions that drug use may have for a subject. We begin with a theoretical discussion, starting with the statement of psychoanalyst Jacques Lacan (1975/1997, our translation) that says there would be "no other definition for drugs, other than this: what allows to break the marriage with the little pee-pee" (p.117). We continue with the elaboration of other psychoanalysts, who, over the years, have discovered that drug use can operate in a way that is different from the rupture with the phallic frame of jouissance. It can, otherwise, limit the devastating effects on the subject. The article seeks to substantiate its argument on the analysis of a clinical case, which calls the Lacanian premise into question, showing that drug use cannot be reduced to a single function.

Keywords: Psychoanalysis; jouissance; drug use; devastation.

Uma das poucas referências na obra de Lacan (1975/1997), e talvez a mais conhecida delas, para se pensar a questão do uso de drogas, foi sua afirmação de que este uso serviria para "romper o casamento com o pequeno pipi" (p. 117). Essa tese foi bastante explorada por psicanalistas desde então, que puderam produzir contribuições importantes a respeito do tema. Miller (1993) destacou que, ao permitir que o sujeito rompa com seus impasses frente à castração e ao gozo fálico, o uso de drogas possibilita uma relação com o gozo do corpo de caráter autoerótico, que pode levar a uma deriva compulsiva e autística, tornando o Outro dispensável. Laurent (2014) demarcou a diferença entre o uso de drogas e o sintoma freudiano, demonstrando que, enquanto o sintoma se amarra à fantasia e dá limite ao gozo pela via do desejo, o uso de drogas opera como uma "formação de ruptura" (p. 20) com a fantasia, produzindo um esmaecimento da formação sintomática e da divisão subjetiva, impulsionando o sujeito ao campo ilimitado e irrefreável do gozo do corpo.
Essa tese, que analisa o uso de drogas em seu caráter de ruptura com a função fálica, aponta para a possibilidade de a toxicomania provocar uma abertura à dimensão da devastação, já que, ao tornar inoperante o balizamento que a fantasia oferece ao campo do gozo, impele a um gozo de caráter indizível, corporal, ilimitado e avassalador. Essa vertente tem sua relevância, pois não é incomum que se encontre na clínica usuários de álcool e drogas que testemunham essa condição que os arrebata. Este foi o caso de uma paciente internada pela primeira vez aos trinta anos, levada ao hospital por uma amiga dos Alcoólicos Anônimos, que a encontrou desacordada em casa após uma tentativa de suicídio por ingestão de álcool, drogas e medicação. Este caso clínico será discutido nesse artigo, fazendo com que nele o estudo do caso possa produzir contribuições teórico clínicas acerca da relação entre a subjetividade e o uso de álcool e drogas — tema de maior importância atualmente.

A relação entre o uso de drogas e a devastação é verificada constantemente na clínica da toxicomania. No entanto, a clínica nos revela que o uso de drogas pode cumprir também outra função, ainda pouco explorada na literatura analítica, mas que chama cada vez mais atenção em função da disseminação do uso de drogas em grande escala na contemporaneidade - período caracterizado por uma espécie de "toxicomania generalizada", como apontou Sinatra (2000).

Ao invés de funcionar como um rompimento com o gozo fálico, o uso de drogas pode exercer o papel de recompor a função fálica que se apresenta precária para um sujeito, de modo que o auxilia a pertencer a um discurso, a ter uma identificação, um lugar numa parceria sintomática ou um lugar no laço social. Nesses casos, a droga, ao contrário de impelir ao incomensurável do gozo do corpo e abrir caminho à devastação, pode assumir o caráter de um elemento que auxilia a fornecer uma limitação ao gozo. O estudo de caso apresentado nesse artigo lança luz sobre essa questão, pois, na trajetória da paciente, o uso de drogas mostrou 
operar, em certo tempo, como um deflagrador à devastação, e, em outro, como um elemento que permitiu sua estabilização em uma parceria amorosa. Mauricio Tarrab (2003) ao citar o uso de álcool feito por Marguerite Duras e descrito em sua obra, chamou atenção para a possibilidade de a droga poder assumir para um sujeito "uma dupla função: de limite e de devastação" (p. 82). Este artigo segue nessa direção, demonstrando os diferentes modos de o uso de drogas operar sobre o campo ilimitado do gozo.

\section{Método}

A análise deste caso clínico fez parte de uma pesquisa de mestrado na qual foram analisados também outros casos no âmbito da questão da toxicomania. Essa pesquisa teve aprovação junto ao Comitê Nacional de Ética em Pesquisa (CONEP, parecer $\mathrm{n}^{\circ} 1663508$ ).

Nesta pesquisa foi utilizado o método clínico da psicanálise enquanto dispositivo produtor de saber e articulação teórico clínica. O método da psicanálise, que foi inaugurado por Freud, não é um método a priori e sim um método vivo de pesquisa que possibilita o acesso ao saber através do trabalho analítico entre o analista e o paciente, realizado em um dispositivo clínico. Segundo Freud (1996b), “a psicanálise constitui uma combinação notável, pois abrange não apenas um método de pesquisa das neuroses, mas também um método de tratamento baseado na etiologia assim descoberta" (p. 227).

A escuta orientada pela psicanálise na instituição (neste caso, um dispositivo público de internação hospitalar) leva em conta o compromisso com o sujeito do inconsciente, operando com noções como o desejo, a demanda, a transferência e o sintoma. Diferencia-se, então, de uma prática pedagógica, frequente em dispositivos de saúde, que busca promover a eficácia terapêutica através de uma condução moralista do sujeito. Ao contrário, o método da psicanálise, que se utiliza, na prática clínica, do exercício da observação e de entrevistas, busca sempre se aproximar da verdade do sujeito em questão.

Sendo assim, a pesquisa foi realizada a partir da ética da psicanálise e baseada no compromisso ético que é designado pela psicologia enquanto profissão, garantindo o anonimato dos pacientes e todo sigilo necessário para preservá-los. Para tanto, nesse artigo, serão utilizados apenas nomes fictícios e divulgadas somente informações estritamente necessárias para o estudo do caso, não sendo nosso objetivo sua análise detalhada, mas sim sua articulação clínica. Nosso interesse é desenvolver as questões que o caso levanta e que podem ajudar a lançar luz sobre uma argumentação teórica. Tudo o que se referir à fala ou escrito da paciente será apresentado entre aspas, devendo ser lido como sua comunicação pessoal ao longo das entrevistas em análise. $\mathrm{O}$ artigo vai apontar quando a citação tratar de uma comunicação pessoal, sem repetir a informação a cada pequeno extrato em sequência, apenas quando a data mudar.

\section{Droga e devastação na relação mãe e filha}

Valéria chegou pela primeira vez ao hospital após ter se separado há poucos meses do último namorado e desde então estava "sem paradeiro", consumindo álcool e crack em grande quantidade e prostituindo-se. Ela apresentava cortes nos pulsos decorrentes de diversas tentativas de suicídio ao longo da vida, que eram sempre tratadas em pronto-socorro. "Estou acostumada, já fiz isso várias vezes", "a vida não vale mais a pena" (comunicação pessoal, dez. 2011). Esta paciente foi hospitalizada quatro vezes ao longo de dois anos em uma instituição para tratamento de álcool e drogas, sempre em função do uso abusivo de substâncias que se associava a um contexto que reportamos à devastação - refletida a partir dos referenciais lacanianos quanto à sexuação. 
No Seminário Mais Ainda (1972-73/1985), Lacan nos apresentou as fórmulas quânticas da sexuação, resultado de anos de estudo sobre esse tema, e cuja elaboração ele já trabalhava desde o Seminário ... ou pior (1971-72/2012). Neste esquema, escrito com matemas lacanianos e quantificadores matemáticos, dividem-se posições do sujeito na sexuação. Uma delas formalizaria a posição masculina, que poderíamos reportar ao Édipo e à castração, campo simbólico do Todo, da mediação fálica e do gozo fálico. A outra formalizaria a posição feminina, que se refere ao além do Édipo, ao gozo feminino, ao campo do Não-Todo, ao que, no desejo feminino, não se deixaria balizar pelo falo. Com isso podemos elucidar a existência de duas lógicas diferentes, que não se complementam, sendo uma suplementar à outra, fazendo inexistir a relação sexual.

Lacan (2003a) situou que a devastação é algo que acontece, primordialmente, na relação mãe e filha. Freud (1996a), em sua obra, ao tratar da sexualidade feminina, já indicava que "a fase de ligação exclusiva à mãe [...] tem nas mulheres uma importância muito maior do que a que pode ter nos homens" (p. 244), a ponto de se referir a ela como uma possível "catástrofe" (p. 253) da qual a menina só escaparia ao se dirigir ao pai como objeto. Ainda que escape, os vestígios dessa relação com a mãe permanecem latentes na mulher, fazendo com que ela repita os traços dessa ligação nas futuras relações com seus parceiros amorosos e fazendo com que a dimensão de catástrofe, de devastação, que fica como saldo dessa relação para o sujeito, possa ser potencialmente revivida ao longo da vida.

Valéria foi abandonada pela mãe e criada pelo pai, com quem morou até seus doze anos. Ela começou a beber com oito anos, escondida do pai, que era alcóolatra. Aos doze, fugiu da casa do pai, indo procurar sua mãe. Largou os estudos e passou a morar com a mãe, com quem "aprendeu a cheirar". A paciente deixou a casa da mãe aos quinze anos, indo morar em uma conhecida área de prostituição da cidade do Rio de Janeiro. Trabalhou como prostituta, faxineira e depiladora. Se "virava sozinha", morando na casa "de um e de outro". Era usuária de álcool, maconha e cocaína, mas também fazia uso esporádico de crack e medicação. Valéria teve cinco filhos de pais diferentes. "Dei todos eles". Sobre esses filhos, contou: "Eu tinha porque encontrava homens que queriam ter filhos e então eu tinha filhos para eles". Neste ponto podemos entrever o que Lacan (2003b) situou a respeito da posição feminina, quanto ao fato de "não haver limites para as concessões que cada uma faz a $u m$ homem: de seu corpo, de sua alma, de seus bens" (p. 538). Valéria tinha filhos para dar aos homens.

A mãe de Valéria teve câncer de útero quando estava grávida dela. Seu pai dizia que não queria filha "cancerosa", sugerindo que sua mãe a abortasse. "Quando minha mãe descobriu o câncer, meu pai não quis mais ela". Diante desse abandono do marido, a mãe de Valéria tentou envenená-lo com chumbinho. Não conseguiu matá-lo, mas abandonou a filha aos seus cuidados. O pai de Valéria era muito rígido, não queria que ela bebesse e a prendia em casa. "Eu era a princesinha dele". "Eu era muito presa, muito restrita", "ele não deixava nem brincar", e se "aprontasse", "ele batia muito" (comunicação pessoal, jan. 2012). Valéria relacionava o início do uso de álcool ao pai, já que começou a beber em casa, escondida dele. Relatava raiva por ter sido tão "presa", conferindo a isso sua inabilidade posterior em lidar com a liberdade. Analisava certas atitudes suas ao longo da vida, como ter tido três namorados negros, como tentativas de "se vingar" do pai, que "não gostava de negros".

A paciente contou que passou a infância insistindo com o pai para conhecer sua mãe. Na casa do pai, "cada semana tinha uma mulher diferente, que eu sempre chamava de mãe". "Eu sempre quis uma mãe". E, então, uma situação traumática ocorreu aos doze anos, quando Valéria fugiu de casa e finalmente conseguiu conhecer sua mãe. Ela contou que a mãe a instigou a dizer na delegacia 
que o pai abusava dela. "Ela disse: fala isso que você vai morar comigo". "E eu idealizava morar com a minha mãe...”.

Podemos ler no gesto tardio da mãe ainda uma resposta ao abandono do marido. Tal como a vingança de Medéia, ${ }^{1}$ ela ergue com a filha uma falsa acusação de abuso sexual contra o pai, ferindo este homem em sua posição simbólica de pai e trazendo consequências desastrosas para a vida da filha. O pai de Valéria não foi capaz de evitar que sua mãe fizesse uso dela nessa espécie de vingança pessoal contra ele. A partir daí, desaparece da vida da filha, deixando-a à mercê de uma relação devastadora com sua mãe.

Valéria dizia que seu "maior arrependimento" foi ter conhecido sua mãe. "Ela fez da minha vida um inferno". "Me tratava como um cachorro". "Me batia, me obrigava a trabalhar e pegar drogas para ela". "Eu comprava, apertava para ela, ela me levava na favela para transportar as drogas e me dava uma garrafa de cachaça" (comunicação pessoal, fev. 2012). Sobre a mãe, dizia que ela era "louca, bêbada e drogada". "Faz escândalos". "É mais cracuda do que eu". Valéria contou que a mãe já havia tido uma internação psiquiátrica no passado.

O relacionamento da paciente com sua mãe se mantinha perturbado mesmo após tornar-se adulta. "Até hoje, se eu for na casa dela, eu bebo, uso, até a gente começar a brigar". Valéria dizia sentir-se sem defesa diante dela, que falava coisas para magoá-la. "O jeito é manter distância dela o máximo possível, porque eu me deixo abalar". No entanto, Valéria não conseguia manter distância. Ela sempre retornava; a demanda de amor à mãe não cessava. "Eu vou lá com o intuito de ser acolhida, ter algum carinho, ela arma alguma cilada para mim e a gente tampa na porrada”.

Na mitologia grega, Medéia, em nome do amor à Jasão, acompanha-o em sua jornada, dedicando-se a ajudá-lo em tudo. No entanto, ao ser traída e abandonada por ele, sacrifica os próprios filhos para vingar-se e feri-lo substancialmente.
Valéria "não se perdoava" por ter denunciado o pai, respondendo ao desejo da mãe, ao compartilhar sua mentira. "Eu fico me culpando, me destruindo. A droga acaba me adormecendo e eu nem lembro disso". "Minha maior dor é aquilo que fiz com meu pai e culpo a mim e a minha mãe a frustração por não ter estudo, ter dado meus filhos, não conseguir ser mãe, ter virado uma prostituta" (comunicação pessoal, fev. 2012).

A obra de Lacan é permeada de referências quanto ao desejo da mãe e à relação entre mãe e filha (Lacan, 1998; 1999; 2016; 1992; 2003a), as quais sustentam que essa é uma relação marcada por não se deter em um campo consistente, estabelecendo-se em um terreno instável que não é totalmente circunscrito pela função estabilizadora do falo. Por não existir um significante que represente a mulher - como é o significante fálico para o menino - falta esse ponto de ancoragem que articule a identificação entre a menina e sua mãe e situe um limite ao gozo. Segundo Lacan (1992), “o desejo da mãe não é algo que se possa suportar assim, que lhes seja indiferente. Carreia sempre estragos" (p. 105).

Lacan (1999) nos ensina que a inscrição do Nome-do-Pai, através da operação da metáfora paterna, é precisamente o que vai possibilitar que a criança não venha saciar o desejo materno, operando uma primeira separação entre a mãe e a criança. Essa operação simbólica produz, em última instância, o significado por trás da ausência da mãe e do objeto de seu desejo. De acordo com Lacan (1999), o significado de sua falta "é o falo" (p. 181). Seu objeto de desejo é o objeto fálico. A inscrição do Nome-do-Pai e do significante fálico como o significante da falta, instituídos pelo complexo de Édipo, produzem um efeito normatizador, tanto no modo como o sujeito vai estruturar sua relação com a realidade, quanto na maneira em que irá se posicionar na diferença sexual.

Segundo Vieira e Barros (2011), "a função do Nome-do-Pai seria de tornar relativo um apetite, 
que sem ele seria infinito" (p. 7). Ou seja, ao ser metaforizado pelo simbólico, o gozo pode ser regulado, limitado, organizado e localizado de algum modo. Podemos dizer, assim, que a inscrição fálica exerce uma função reguladora importante, à qual nos referimos nesse artigo como a função estabilizadora do falo.

No trabalho clínico por nós realizado, encontramos na escuta dessa paciente um traço que costuma se repetir na clínica da toxicomania: a existência de uma relação conturbada entre mãe e filha, vivida de maneira conflituosa, com pouco auxílio de uma mediação paterna. No caso de Valéria, havia uma ausência de limite presente nos dois lados, tanto no capricho e na rigidez do pai, quanto na loucura desvairada da mãe, o que sugeria uma precariedade da metáfora paterna na constituição da paciente. Em decorrência dessa precariedade, Valéria tinha problemas em se servir da função estabilizadora do falo e permanecia imersa em uma relação mãe e filha marcada por um excesso pulsional que tendia ao campo ilimitado do gozo.

Nesse contexto, a paciente recorria ao álcool e à droga de modo a tentar introduzir um elemento mediador nessa relação devastadora estabelecida com a mãe. No entanto, nesse caso, o uso da droga só fragilizava a dimensão fantasística e obstruía a formação sintomática, abrindo ainda mais a dimensão da devastação. Assim, surgia um "desejo de morrer o tempo todo", que se associava a "uma vontade incontrolável de beber". "Bebo qualquer coisa, até gasolina, para esquecer tudo que passou, ficar dormente". Nos momentos mais difíceis, ficava "trancada em casa querendo beber, com o psicológico péssimo, cansada da vida difícil, pensando em morrer". Por vezes não suportava, passando ao ato. Bebia "tudo dentro de casa", da acetona ao álcool de cozinha. "Eu bebo até cair. Eu fico apagada. Esqueço de tudo". "Quando eu bebo fico assim: podre, vulgar, um lixo, o resto das mulheres, igual minha mãe" (comunicação pessoal, abril 2012).
A devastação pode ser pensada, na obra de Lacan (2003a), como um modo de apresentação do gozo que ilustra de maneira marcante a relação do sujeito com o significante da falta no Outro sem a mediação fálica, e seus efeitos de "abolição subjetiva" (Soler, 2005, p. 186). O ensino de Lacan (2012) nos mostra que não é viável se pensar a linguagem sem essa articulação ao vazio, sem esse vazio suplementar que a fura, que Lacan escreve com o símbolo $\mathrm{S}(\AA)$, com o qual pretende marcar "esse Outro [Autre] como vazio" (p. 97). Trata-se de um vazio fundante, a partir do qual se produz a necessidade do discurso, que, por sua vez, se dirige a esse vazio e o contorna. Ainda assim, algo desse vazio estrutural resta sem que possa ser traduzível em palavras, passando ao largo do discurso, e indicando a presença do indizível, impossível de abordar por foracluir o sentido e não se ligar a nada (Lacan, 2007a, pp. 115-124).

Isso que escapa ao significante ex-siste enquanto gozo do corpo, situando-se num campo não recoberto pela palavra, num campo além do simbólico e da mediação fálica. Em função disso, é sempre difícil articular algo a respeito desse gozo do corpo, que Lacan, no Seminário Mais Ainda (1972-73/1985), nomeou de gozo feminino. É um gozo "indizível” (p. 119), por se sustentar no vazio, na ausência de significante no Outro $S(A)$. Segundo Laurent (1999), "todos nós temos de lidar com esse ponto de linguagem" (p. 110, tradução nossa), ${ }^{2}$ e por isso o gozo feminino, apesar de ser nomeado feminino, não é exclusivo da mulher, já que esse além da lógica fálica é característica da linguagem e pode se dar para qualquer ser falante. Trata-se do gozo sem borda, de localização imprecisa em relação ao corpo. Tudo o que a lógica fálica trata em relação ao gozo - localizando-o no corpo, limitando o gozo, situando sujeito e

\footnotetext{
No original: "todos tenemos que enfrentarnos con ese punto del lenguaje. Algunas mujeres logran mostrar cómo se puede tener la relación más estrecha con ese punto" (Laurent, 1999, p. 110).
} 
objeto causa do desejo na estrutura da fantasiasuspende-se, o que produz vulnerabilidade. $\mathrm{O}$ gozo feminino está, justamente, fora da função estabilizadora do falo, como vínhamos tratando, o que o faz assumir uma conotação avassaladora, devastadora, que arrasta o sujeito ao ilimitado do campo do Outro.

Dessa forma, a devastação não pode ser reduzida ao estatuto de uma experiência como a angústia, ou equiparada a um estado emocional como a tristeza. O gozo feminino, por seu caráter de gozo, está para além de qualquer dimensão simbólica e imaginária; e, por seu caráter distinto do gozo fálico, subsiste sem fronteiras definidas. É desse modo que podemos pensar a condição que arrebatava Valéria, em sua errância e ideação suicida, potencializadas pelo uso de álcool e drogas. Era a devastação que a arrebatava. Em um de seus bilhetes, ela escreveu:

Não acho que lembrar do meu passado vai me ajudar muito. Refletir sobre ele só me dói. Eu não vejo solução nisso. Já sei o que ocasionou tudo isso. Sei que foi a covardia que fiz com meu pai, os maus tratos e a falta de amor do meu pai, as agressões verbais e físicas da minha mãe, profetizações maléficas da minha mãe e a facilidade de drogas que minha mãe me forneceu. A guerra que tenho com minha mãe é falta de amor dela e falta de serenidade minha. (comunicação pessoal, abril 2012)

Essa "falta de amor" da mãe e suas "profetizações maléficas" eram respostas que Valéria obtinha diante de sua demanda incessante, o que tomava para ela a dimensão de uma guerra devastadora.

Esta mãe, que era "catadora de lixo" e usuária de drogas, não cansava de proferir insultos à filha. Ela repetia para Valéria: "você é meu câncer". Essa frase marcava a paciente e retornava quando ela pensava sobre suas tentativas de suicídio. A "vontade de sumir, de morrer", capturava-a com frequência. Nos atendimentos, ela tentava construir algo a respeito da devastação, tecer algum arranjo que enlaçasse esse indizível. Assim, lembrava da voz da mãe dizendo-lhe: "você é meu câncer". "Eu sou o câncer da minha mãe". "Acho que isso ficou gravado. Ficou marcado em mim. Tenho que aprender a ser de outro jeito".

Nisso que ficou gravado, marcado no corpo de Valéria, podemos ver o rastro do arrebatamento materno. Neste ponto, verificamos, como afirma Brousse (2004), que

... surge [...] a fixidez de um objeto de gozo que bloqueia, como tropeço, a deriva metafórica dos significantes-chave, e rebaixa o sujeito ao ser do objeto que ele foi para o Outro: negação da falta-a-ser e designação de um ser como objeto rebotalho. (p. 62)

Câncer da mãe marcava uma posição de gozo - por vezes enlaçado pela fantasia, mas sempre de maneira frágil. Ao procurar a mãe na infância, buscando em seu amor a completude, costumava receber dela outras coisas, tais como: "porrada", "garrafa de cachaça", o olhar dado a "um cachorro", a voz que a designava como "câncer". A frágil dimensão fantasística esbarrava aí em um ponto difícil de significantizar, o que tornava Valéria mais suscetível à devastação.

A queda de Valéria como objeto rebotalho, destacada de qualquer amarração simbólica, era sempre uma ameaça iminente. Quando já não havia nenhuma circunscrição simbólica imaginária que servisse de suplência, Valéria encontrava a deriva, a errância, a devastação. Ficava, como dizia, "perdida, sem destino, com a cabeça avoada, dormindo em laje pelo morro, namorando bandido". No contexto da devastação, o uso de álcool e drogas era buscado pela paciente para "apagar", "esquecer", "ficar dormente", e, assim, seguia a direção de impulsioná-la mais ainda ao campo ilimitado do gozo. Não era incomum, nessa conjuntura, que a droga fizesse parte ativa de uma tentativa de 
suicídio, por exemplo. Valéria dizia se encontrar com "a decadência", e ficar "entregue à derrota". Sem limite, bebia até cair. Experimentava o lado mortífero do gozo. Por fim, tornava-se um corpo caído no chão, um corpo na laje, pensando em suicídio. Esse corpo-lixo, desfalicizado e perdido, desvelava-se como puro objeto caído da mãe. Poderíamos afirmar que Valéria se reduzia à:

... carne que jamais se vê, o fundo das coisas, o avesso da face, do rosto, os secretados por excelência, a carne da qual tudo sai, até mesmo o íntimo do mistério, a carne, dado que é sofredora [...]. Visão de angústia, identificação de angústia, última revelação do és isto - és isto, que é o mais longínquo de ti, isto que é o mais informe. (Lacan, 2010, p. 211)

Só é possível pensar a devastação no campo da relação entre o sujeito e o Outro. Ela é associada, fundamentalmente, à relação mãe e filha, mas também pode se apresentar em outras parcerias sintomáticas. Essa situação clínica pode se dar em qualquer parceria que se conduza no campo desse gozo que tende ao ilimitado, e que não conta com uma circunscrição fálica eficaz em localizá-lo de algum modo. Para Valéria, a dimensão da devastação costumava se abrir frente a situações vividas nas parcerias amorosas (dos sutis desencontros aos mais violentos abandonos); ou no laço familiar, como quando a tia lhe disse que não poderia ficar com ela, porque ela era "um peso muito grande". Nesses tropeços, Valéria caía, e o que ela experimentava estava fora de qualquer circunscrição fálica, era o gozo feminino que a capturava de um modo devastador.

\section{Uso de drogas e parceria amorosa}

A clínica nos evidencia como o sujeito está sempre em busca de recursos que o auxiliem a tratar essa impetuosidade do gozo, essa alteridade radical e avassaladora, buscando cingir isso que, no corpo, é vivido como Outro. Tais recursos poderão ser tantos quanto cada um puder inventar para si. $\mathrm{Na}$ atualidade, a clínica nos abastece de casos nos quais o uso de álcool e drogas se torna um dos pontos a compor essa tessitura viva que constitui a solução singular de cada um para lidar com os efeitos devastadores do gozo. Esse artigo aborda, justamente, como o uso de álcool e drogas pode ser utilizado pelo sujeito como um recurso frente à insistência, sem regulação ou contorno, desse gozo que pode se apresentar sob o aspecto da devastação em uma relação familiar ou parceria amorosa.

A parceria amorosa era algo que Valéria buscava insistentemente. Notava-se o modo como, durante a internação, ela tentava encontrar um parceiro entre os pacientes. Costumava queixar-se da solidão como algo insuportável, e então, buscava ativamente a companhia dos homens. Chegou a construir, em sua primeira internação, uma parceria amorosa com um deles. Poucos dias depois da alta, retornou pedindo nova internação após uma recaída, que relacionava a ter sido deixada por esse namorado. "Foi desilusão amorosa. Eu não aguentei que ele não voltou". "Não gosto de ficar sozinha" (comunicação pessoal, maio 2012).

Sozinha, Valéria se sentia "desamparada", “sem lugar, sem família, sem ninguém”, e ficava "sem paradeiro", com vontade de morrer. Muitas vezes, nesses momentos, encontrava solução "indo para a pista". "Sozinha não dá. Não consigo. Dá depressão. Vou me drogar, nem adianta. Vou para a pista me prostituir". "A prostituição também é um vício". "Eu sou muito dependente, preciso de alguém do meu lado". Valéria apontava que havia um desamparo, impossível de nomear, que ela tentava tratar pela via da parceria amorosa, que quase sempre era acompanhada pelo uso de drogas, como tentativa de lidar com o mal-estar. Podemos remeter essa "solidão insuportável” à solidão do gozo feminino, que se dá, segundo Bassols (2016), "quando o sujeito é confrontado à sua própria ausência. É uma solidão elevada à segunda potência, difícil de 
alcançar [...] porque é uma ausência que remete somente à outra ausência" (p. 15, tradução nossa) 3 $^{3}$.

Em seus escritos, Valéria costumava se referir a ela e a sua vida com palavras que representavam o objeto-lixo, o dejeto, como, estar "na vala", "na sarjeta", ser "podre", "vulgar", "resto das mulheres". Esse lixo nunca era catado pela mãe. Esse resto nunca era catado, a não ser por algum homem. E no momento em que estabelecia uma parceria amorosa, Valéria parecia encontrar alguma estabilidade, um lugar possível que, no entanto, não deixava de fora a marca da devastação - que permanecia como resto indecifrável ante o fracasso da fantasia.

A companhia de um homem, até mesmo fora de uma parceria amorosa, era apaziguadora para Valéria. Na prostituição, Valéria sentia-se valorizada por seus clientes, que chamava de "tiozinhos". "Me apego aos homens assim ó [estala os dedos]'. Na "pista", ela vestia o semblante da prostituta, mulher desejada, e nesse revestimento fálico, encontrava algum alívio. Valéria, assim, tomada como objeto por um homem em sua fantasia, estava vestida da fantasia masculina. Isso era, de algum modo, apaziguador para ela, pois circunscrevia, fazia limite para o que nela tendia ao ilimitado do gozo feminino e à fixidez da posição de objeto-dejeto na devastação. No "vício da prostituição" aparecia uma circunscrição de gozo, um limite.

Após a alta da sua terceira internação, Valéria não ficou no abrigo indicado, voltando para as ruas, para a prostituição e para as drogas. Foi nesse tempo que conheceu Bruno. "Ele me tirou da pista". Valéria foi morar com ele e procurava um emprego, até que uma crise de ciúmes de Bruno desencadeou um rompimento. Quando Valéria arrumou "um bico para passar roupa na casa de um patrão", Bruno desconfiou dela, interpelando-a e provocando uma briga que culminou em agressões, injúrias, e na

No original: "la soledad del goce femenino, cuando el sujeto queda confrontado a su propria ausencia. Es una soledad [...] elevada a la segunda potencia, difícil de alcanzar. En realidad es una ausencia y una soledad para nadie, porque es ausencia solo para otra ausencia" (Bassols, 2016, p. 15). afirmativa dele de que a queria fora de casa. Sobre isso Valéria disse: "Não aguentei. Fui à cozinha e tomei uma garrafa de álcool [de cozinha]. Quebrei tudo". Em seguida foi ao hospital pedir nova internação, "porque não queria continuar me drogando" (comunicação pessoal, jan. 2013).

A paciente portava cicatrizes no corpo e escoriações no rosto. Se antes as marcas no corpo se davam por suas quedas, quando "caía bêbada de cara no chão", e pelos cortes nos pulsos, quando tentava suicídio, agora elas eram circunscritas às "porradas" do parceiro, que a agredia constantemente por ciúmes. Seu corpo era assim marcado pela violência, seja a que vinha de si própria, gozo feminino que a arrebatava pela via da devastação, seja a que vinha da relação com o Outro, gozo fálico que demarcava sua relação com o parceiro. Ele, com frequência, proibia-a de trabalhar fora e a agredia.

Durante a internação, a paciente mostrava-se arrependida de seu ato em casa e com medo de perder o companheiro. Ela disse: "aqui posso dizer que sinto falta dele sem ser julgada". Valéria se oferecia nessa posição de objeto em sua dimensão fantasística. Podemos reconhecer, nesse ponto, a fantasia infantil que Freud (1996c) localizou no texto "Uma criança é espancada" (pp. 193-218), que se tornou paradigmática por sinalizar que a fantasia pode ser, ao mesmo tempo, marcada pelo princípio do prazer e seu mais além, fazendo equivaler objeto espancado e objeto privilegiado de amor do pai. Apesar da violência do parceiro, Valéria dizia: "ele gosta de mim, e eu sou como um cachorrinho abandonado. Um carinho e eu já gosto". "Com ele sinto segurança. Sempre que algo falta ele dá um jeito e consegue. Igual meu pai" (comunicação pessoal, fev. 2013).

Em seus relatos, Valéria apontava que havia encontrado um lugar possível nessa parceria amorosa. Dizia ter encontrado "uma família", já que sentia que a família dele a acolhia. Ela tentava diminuir o uso de drogas junto com ele que, apesar de ser também usuário de álcool e cocaína, ajudava-a de 
uma maneira singular a regularizar esse gozo. " $\mathrm{Eu}$ estava conquistando aos poucos o que eu queria. Casa, marido, a confiança dos pais dos meus filhos e um emprego". "Começando a me sentir gente. Antes eu era um projeto. Um projeto de gente". Valéria voltou para esse namorado no fim da internação, seguindo nesse relacionamento amoroso, que trouxe para ela alguma estabilidade, o que a fez prescindir de outras internações por anos.

A estabilização na parceria amorosa se dava através de um arranjo singular e frágil que, ainda assim, possibilitava uma circunscrição do gozo. Na maior parte do tempo, Valéria se dividia entre ficar em casa e acompanhar o marido catando latinhas na rua. Bruno regulava o uso de cocaína de Valéria, porque fazia bicos e levava uma pequena quantidade de cocaína para ela diariamente. Ela se incomodava por ele "comprar o pó" dela, mas o marido não reclamava. Queixava-se, querendo trabalhar e ter alguma independência. "Ele diz que não precisa [trabalhar], mas eu preciso de um tempo para mim porque senão fico dependente da pessoa". Então, além de catar latinhas com o marido, ela atuava algumas vezes como manicure e tentava arrumar um emprego. As brigas e discussões giravam em torno dessa queixa e demanda de Valéria, que acabavam por desencadear os ciúmes de Bruno e suas agressões. Observamos como havia, então, um arranjo particular no relacionamento que a fazia, por um lado, dependente dele, e, por outro, queixando-se e buscando uma mínima autonomia. Por um lado, oferecia-se como objeto, por outro, fazia oposição a isso - deixando aparecer aí um saber próprio a respeito do risco que lhe concernia: o de assumir inteiramente esse lugar de objeto, desaparecendo como sujeito, na devastação.

A parceria amorosa era, assim, uma conjuntura na qual se exercia alguma regulação do gozo. Como vimos, Valéria costumava associar Bruno ao pai, situando-o como aquele que lhe dava segurança; batia, mas gostava dela. Além disso, ele a impedia de certas realizações e dizia-lhe palavras de injúria, o que também o associava à mãe. Essa relação tinha, então, alguma sustentação no amor e na fantasia, permitindo, assim, uma regulação e uma localização do gozo.

Se lembrarmos como o álcool era um objeto especial situado entre Valéria e sua mãe, já que a "garrafa de cachaça" era uma das coisas que Valéria ganhava da mãe em resposta à sua demanda de amor; a cocaína era o que ela recebia do marido. Mas, enquanto o álcool ligava-se à devastação entre mãe e filha, convertendo-se em uma espécie de $o b$ jeto-devastação para a paciente, a cocaína produzia um efeito inverso, tornando-se um objeto que visava neutralizar os efeitos do campo ilimitado do gozo na parceria amorosa. Valéria dizia: "uso cocaína para não beber acetona". É interessante notar, no entanto, que a cocaína só detinha essa função porque passava pelo parceiro do amor. Neste caso, a cocaína "já não é tanto o parceiro, mas aquilo que a acompanha na relação com o parceiro" (Naparstek, 2014, p. 150).

A cocaína era o objeto fálico investido pelo casal como objeto mediador, oferecido pelo marido à mulher, como signo do amor. Nessa parceria sintomática, poderíamos pensar que a cocaína entrava na hiância entre o homem e a mulher encobrindo o real da inexistência da relação sexual, tornando-se uma defesa contra a angústia e contra a irrupção de um gozo ilimitado. Para esse casal, o uso da cocaína detinha um papel que diverge do rompimento com a função fálica, servindo a uma amarração singular da parceria amorosa.

A mediação que a droga realizava, ao contrário de romper com o gozo fálico, contribuía para um enquadramento fálico da parceria amorosa, de modo a evitar os efeitos de devastação ou absolutização do amor que poderiam se dar, para Valéria, em uma parceria sintomática. Assim vemos como a droga pode se tornar "uma muleta para acessar o outro sexo" (Naparstek, 2008, p. 60), não se convertendo no parceiro exclusivo do sujeito, mas acompanhando uma parceria sintomática e, até mesmo, estabilizando-a. 


\section{Discussão}

Analisamos, primeiramente, como o uso de álcool e drogas servia à paciente como um elemento que vinha romper com a função fálica, de modo a dar continuidade ou potencializar um gozo ilimitado e devastador. Esse uso se relacionava diretamente à devastação materna. Nesse caso, a droga era usada por Valéria para "esquecer", "apagar", e até mesmo "sumir" ou "morrer", e, assim, respondia ao vazio no Outro não formando um sintoma, mas no real, com a abolição subjetiva própria à devastação.

Se retomarmos a questão tratada nesse artigo, quanto à dupla função que o uso de drogas pode exercer em relação à devastação, vemos que, nesse ponto, o uso exercia para Valéria uma função que estava em consonância com a tese lacaniana de $1975 .{ }^{4}$ A droga se tornava a única e derradeira parceira de Valéria, produzindo um verdadeiro desenganche do Outro, e tornando a função estabilizadora do falo praticamente inoperante.

Já em outro momento, Valéria se encontrou com outra função do uso de drogas em sua vida. A droga não mais a apartava do Outro e mobilizava um gozo irrefreável; ao contrário, tornava-se o anteparo de uma parceria amorosa. Nesse ponto, como situou Naparstek (2002), o uso de drogas não segue a lógica da ruptura, mas ganha o estatuto de uma "solução sintomática" (p. 36). Seguindo em direção contrária à devastação, a droga se associa a um parceiro e, ao invés de tornar inoperante a função estabilizadora do falo, se apresenta como um elemento mediador, que pode ser investido libidinalmente em uma parceria sintomática. Isso faz com que se situe um limite, uma circunscrição do gozo. Segundo Naparstek (2002):

Neste ponto se ressalta o lugar do parceiro sexual [...] um parceiro que, junto ao consumo, permite localizar sintomaticamente e singularmente o gozo.

Ver na obra de Lacan: Intervenção de encerramento das jornadas de cartéis da Escola Freudiana de Paris (1997).
Um gozo que com essas condições pode passar ao campo do Outro e enlaçar-se a um parceiro. [...] uma vez que as coisas são estabelecidas nessa ordem, o problema de como enfrentar sexualmente seu parceiro torna-se o que se põe em jogo como aflição. (p. 36, tradução nossa) ${ }^{5}$

Nessa estabilização pela via do amor, Valéria se afligia com questões próprias à parceria amorosa - como ciúmes, autonomia etc. - sem que, no entanto, deixasse de lado o uso de drogas. Nesse contexto, a droga se torna "uma muleta" que permite ao sujeito sustentar o casamento com o falo, ou "uma costura" que permite seu enlace a um parceiro sintomático que o localiza.

\section{Considerações finais}

Nesse artigo vimos como, em um mesmo caso, a prática do uso de drogas pode exercer uma dupla função em relação à devastação, qual seja, a de provocar uma abertura à dimensão da devastação, ou a de ser parte de um arranjo particular na vida de um sujeito que permite uma localização e limitação do gozo, tendendo, justamente, a evitar o "pior" - um dos nomes dados à devastação, por Lacan (2007b, p. 98).

De acordo com o que tratamos nesse artigo, se faz necessário destacar, junto a Naparstek (2010), que "é fundamental ver que função o consumo de drogas cumpre para cada sujeito antes de tentar

No original: "se ve que hay un uso resolutorio que no sigue la lógica de la ruptura. En este punto se resalta el lugar del partenaire sexual como localizador sintomático del goce [...] Se ve aquí el estatuto de resolución sintomática que tiene el partenaire como vía oficial y una práctica clandestina de consumo a su lado. Se trata de un partenaire que junto al consumo permite localizar sintomáticamente y singularmente el goce. Un goce que con estas condiciones - manteniendo a un costado lo íntimo - puede pasar al campo del Otro y enlazarse con un partenaire. No hay que dejar de señalar que una vez establecidas las cosas con este orden el problema de cómo enfrentarse sexualmente a su partenaire se transforma en lo que se pone en cruz" (Naparstek, 2002, p.36). 
removê-lo, observar se tem a função de estabilizar algo e de que maneira estabiliza ou não, e, a partir disso, ver o que fazer" (p. 83, tradução nossa). ${ }^{6}$ Ressaltamos ainda que, apesar de o uso de drogas mostrar ser, em alguns casos, uma solução sintomática estabilizadora, pode ser encarada como uma solução de caráter frágil e provisório.

\section{Referências}

Bassols, M. (2016). Lo femenino, entre centro y ausência. Texto produzido para XV Jornada da Escuela Lacaniana de Psicoanálisis del Campo Freudiano, Madrid. Disponível em http://mujeres.jornadaselp.com/textos-de-orientacion/ textos-de-orientacion-lo-femenino-entre-centro-y-ausencia

Brousse, M. H. (2004). Uma dificuldade na análise das mulheres. Em J. A. Miller. (Org.), Ornicar? De Jacques Lacan a Lewis Carrol (pp. 57-67). Rio de Janeiro: Jorge Zahar Ed.

Freud, S. (1996a). Sexualidade feminina. Em Obras Psicológicas Completas de Sigmund Freud: Edição Standard Brasileira, vol. 21 (pp. 239257). Rio de Janeiro: Imago Ed. (Texto originalmente publicado em 1931).

Freud, S. (1996b). Sobre a psicanálise. Em Obras Psicológicas Completas de Sigmund Freud: Edição Standard Brasileira, vol. 12 (pp. 225231). Rio de Janeiro: Imago Ed. (Texto originalmente publicado em 1913).

Freud, S. (1996c). Uma criança é espancada: uma contribuição ao estudo da origem das perversões sexuais. Em Obras Psicológicas Completas de Sigmund Freud: Edição Standard Brasileira, vol. 17 (pp. 193-218). Rio de Janeiro: Imago Ed. (Texto originalmente publicado em 1919).

$6 \quad$ No original: "Es central ver qué función cumple el consumo para cada sujeto antes de apuntar a sacarlo, observar si eso tiene la función de estabilizar algo y de qué manera lo estabiliza o no y a partir de ahí ver qué hacer" (Naparstek, 2010, p.83).
Lacan, J. (1985). O Seminário, livro 20: mais, ainda. Rio de Janeiro: Jorge Zahar Ed. (Seminário originalmente proferido em 1972-1973).

Lacan, J. (1992). O Seminário, livro 17: o avesso da psicanálise. Rio de Janeiro: Jorge Zahar Ed. (Seminário originalmente proferido em 1969-1970).

Lacan, J. (1998). A significação do falo. In: Escritos (pp. 692-703). Rio de Janeiro: Jorge Zahar Ed. (Texto originalmente publicado em 1958).

Lacan, J. (1997). Intervenção de encerramento das jornadas de cartéis da Escola Freudiana de Paris. In Documentos para uma Escola - Escola Letra Freudiana, ano 1, $n^{\circ} 0$ (pp. 110-119). Rio de Janeiro: publicação interna. (Texto originalmente publicado em 1975).

Lacan, J. (1999). O Seminário, livro 5: as formações do inconsciente. Rio de Janeiro: Jorge Zahar Ed. (Seminário originalmente proferido em 1957-1958).

Lacan, J. (2003a). O Aturdito. Em Outros Escritos (pp. 448-500). Rio de Janeiro: Jorge Zahar Ed. (Texto originalmente publicado em 1973).

Lacan, J. (2003b). Televisão. Em Outros escritos (pp. 508-543). Rio de Janeiro: Jorge Zahar Ed. (Texto originalmente publicado em 1974).

Lacan, J. (2007a). Do sentido, do sexo e do real. Em O Seminário, livro 23: o sinthoma. (pp.115-124). Rio de Janeiro: Jorge Zahar Ed. (Seminário originalmente proferido em 1975-1976).

Lacan, J. (2007b). Joyce e as falas impostas. Em $O$ Seminário, livro 23: o sinthoma. (pp.88-98). Rio de Janeiro: Jorge Zahar Ed. (Seminário originalmente proferido em 1975-1976).

Lacan, J. (2010). O seminário, livro 2: o Eu na teoria de Freud e na técnica da psicanálise. Rio de Janeiro: Jorge Zahar Ed. (Seminário originalmente proferido em 1954-1955).

Lacan, J. (2012). O Seminário, livro 19: ... ou pior. Rio de Janeiro: Jorge Zahar Ed. (Seminário originalmente proferido em 1971-1972).

Lacan, J. (2016). O seminário, livro 6: o desejo e sua interpretação. Rio de Janeiro: Jorge Zahar Ed. (Seminário originalmente proferido em 1958-59). 
Laurent, E. (1999). Posiciones femeninas del ser. Del masoquismo femenino al empuje a la mujer. Buenos Aires: Editorial Tres Haches. (Texto originalmente publicado em 1993).

Laurent, E. (2014). Três observações sobre a toxicomania. Em M. Mezêncio, M. Rosa, \& M. Wilma (Orgs.), Tratamento possivel das toxicomanias... com Lacan (pp.19-25). Belo Horizonte: Scriptum. (Texto originalmente publicado em 1988).

Miller, J. A. (1993). Para una investigación sobre el goce auto-erótico. Em E. S. Sinatra, D. Sillitti, \& M. Tarrab (Orgs.), Sujeto, goce y modernidad: los fundamentos de la clínica (pp. 13-21). Buenos Aires: Atuel. (Texto originalmente publicado em 1989).

Naparstek, F. (2002). De la ruptura a la resolución del partenaire sintomático. Em Sessões simultâneas pelos grupos do campo freudiano (pp. 35-37). Rede TyA Brasil, publicação interna.

Naparstek, F. (2008). Los goces y la toxicomania. In Introducción a la clínica con toxicomanías y alcoholismo, $2^{a}$ ed. (pp. 51-62). Buenos Aires: Grama Ediciones.

Naparstek, F. (2010). La orientación lacaniana con toxicomanías y alcoholismo. In Introducción a la clínica com toxicomanías y alcoholismo III, $1^{a}$ ed. (pp. 71-84). Buenos Aires: Grama Ediciones. Naparstek, F. (2014). De homens e mulheres. In M. Mezêncio, M. Rosa \& M. Wilma(Orgs.), Tratamento possivel das toxicomanias com Lacan (pp.143-157). Belo Horizonte: Scriptum.

Sinatra, E. (2000). La toxicomanía generalizada y el empuje al olvido. In D. Sillitti, E. Sinatra \& M. Tarrab, (Orgs.), Más allá de las drogas: estúdios psicoanalíticos (pp. 39-61). La Paz: Plural Editores.

Soler, C. (2005). O que Lacan dizia das mulheres. Rio de Janeiro: Jorge Zahar Ed.

Tarrab, M. (2003). Algo peor que un síntoma. Em S. Botto, N. Naparstek, \& L. D. Salamone (Orgs.), El psicoanálisis aplicado a las toxicomanías (pp. 75-85). Buenos Aires: publicação interna. Vieira, M. A., \& Barros, R. R. (2011). Mães Lacanianas: A mãe da devastação. Curso Livre do ICP-RJ, ocorrido na Escola Brasileira de Psicanálise, Seção Rio, em 27/10/2011 [transcrição de Daniele Menezes, notas de Angélica Tironi, revista pelos autores]. (pp.1-13). Disponível em http://www.litura.com.br/curso_repositorio/ maes lacanianas iii pdf 1.pdf
Recebido: maio 30, 2019 Aprovado: fevereiro 5, 2020 